\title{
EFFECT OF SOIL MOISTURE STATE ON THE SURFACE RUNOFF AND SOIL LOSS UNDER NATURAL PRECIPITATION
}

\author{
Khalid F. Hassan \\ Soil and Water Sci. Dept., College of Agri. \\ and Forestry, Mosul Univ. \\ Mohanned A. Al-Shamma \\ Ministry of sciences and Technology, \\ Directory of Agricultural Researches \\ E-mail: Khalid_a222@yahoo.com
}

\begin{abstract}
Field experiment was preformed to determine the effect of soil moisture state on the runoff volume and soil loss by using standard flumes with dimension of $100 * 12 * 30 \mathrm{~cm}$. The flumes were filled with soil materials $<4 \mathrm{~mm}$ in diameter and leveled at a slope $2 \%$. Some of the flumes were moistened and others were left dry. All the flumes were exposed to the natural precipitation.

The results of this study pointed out that the moist state primarily appeared increasing the runoff volume and soil loss in comparison with dry state. The rate of soil loss under water erosion was found to be proportionally related with the soil moisture content. Also the results of the statistical analysis by regressing rainfall depth against runoff depth showed that threshold value of the surface runoff resulted from moist soil state were less than that of dry state.
\end{abstract}

Keywords: water erosion, runoff, soil moisture, rainfall erosivity.

Received: 20/9/2012, Accepted: 18/3/2013.

\section{INTRODUCTION}

Hydrological condition of watershed is the most important factor influenced runoff and soil loss by water erosion. Recent studies of water erosion have been indicated that the erosion rate in relation to the surface runoff and soil loss are commonly attributed to the interaction effectiveness of rainfall erosivity (R) and soil erodibility $(\mathrm{K})$ as in the following functional relationships:

Erosion Rate $=f\left(\mathrm{R}^{*} \mathrm{~K}\right)$

The rainfall erosivity factor $\mathrm{R}$ is the potential ability of rain to cause surface runoff and flow of unprotected soils. The best rainfall parameter to characterize is the $\mathrm{EI}_{30}$ value which computed as follow (Wischmeir and Smith 1978);

$\mathrm{EI}_{30}=\mathrm{E} * \mathrm{I}_{30}$

Where;

$\mathrm{E}=$ Rainfall kinetic energy (Joule), and

$\mathrm{I}_{30}=$ Maximum rainfall intensity at a $30-$ minute period $(\mathrm{mm} / \mathrm{hr})$.

Rainfall energy (E) of each rainstorm is computed as follows:

$\mathrm{E}=210.3+89 \log _{10} \mathrm{I}$

Part of M.Sc. thesis of the $2^{\text {nd }}$ author. 
While the soil erodibility factor $\mathrm{K}$ is defined as the resistance of the soil to both detachment and transported. It varies with soil textured, aggregate stability, shear Strength, infiltration capacity and organic matter content .

The effect of water erosion upon surface runoff and soil loss is a function of its effect upon such factors directly related to the physical conditions of the soil surface (Dennis and Bryan 2000). The more important of these, is the soil moisture state or existing moisture already present in the soil. This hydrological term describing the relative wetness condition which influence the rate of runoff- infiltration relationship..

Because soil moisture state has a majority contribution to surface runoff and soil loss by water erosion of dry land regime at northern Iraq. For this reason, a field experiment was conducted to determine the effect of initial soil moisture state (dry and moist) on the surface runoff and soil loss under natural precipitation of northern Iraq.

\section{MATERIALS AND METHODS}

The study was conducted under climatic condition of Mosul city which located at $43^{\circ} 08^{-} \mathrm{E}$ and $36^{\circ} 20^{-} \mathrm{N} /$ northern Iraq. Climatologically, the area isbelong to semi - arid zone because the mean annual rainfall of the last 30-yrs was about (375 $\mathrm{mm})$.

The experiment was preformed using a Standard flume (as described by Chaudry et. al.1978) with dimension $100 * 12 * 30 \mathrm{~cm}$. The flume was filled with a selected airdried fine - textured soil. The soil used was a Mosul silty clay soil which classified within great group of Calciorthids according to the USA soil taxonomy (USDA, 1975). Some physical and chemical properties of the studied soil are presented in table (1).

Table (1) : Physical and chemical properties of the studied soil

\begin{tabular}{|c|c|c|c|c|c|c|c|}
\hline Clay & Silt & Sand & \multirow{2}{*}{ Texture } & \multirow{2}{*}{$\mathrm{pH}$} & $\mathrm{EC}$ & O.M. & $\mathrm{CaCO}_{3}$ \\
\cline { 1 - 2 } \cline { 5 - 7 } & $\mathrm{g} / \mathrm{kg}$ & $\mathrm{dS} / \mathrm{m}$ & \multicolumn{2}{|c|}{$\mathrm{g} / \mathrm{kg}$} \\
\hline 432.7 & 412.3 & 155.0 & Silty Clay & 7.23 & 0.373 & 5.55 & 266.2 \\
\hline
\end{tabular}

Some of these flumes were moistened and the other left dry. The flume was leveled at slopes $2 \%$. Soil sample $<2 \mathrm{~mm}$ in diameter. In addition, sample from studied soil was analyzed for non-clay fractions (silt + sand), organic matter content, permeability and structure class (Table 2) using the methods describing by klute (1986). Erodibility (K-factor) of this soil was predicted by using soil erodibility nomograph of Wischmeir and Smith (1978).

All flumes were exposed to the natural precipitation of rainy season 2005-2006 (from October 2005 to May 2006). The calculation of the rainfall erosivity in this study was based on the analysis of rainfall charts for rainstorm measurements by using recorder rain gauge instrument. Rainfall charts of these rainstorms were analyzed for unit kinetic energy, the kinetic energy per unit area and unit volume of rainstorm to calculate throughfall kinetic energy, maximum rainfall intensity at 30-minute and the combination of them $\left(\mathrm{EI}_{30}\right)$. 
Table (2): Soil erodibility factor (K) and soil dependent - properties.

\begin{tabular}{|c|c|c|c|c|c|}
\hline Sand & Vfs + silt & $\begin{array}{c}\text { Organic } \\
\text { matter }\end{array}$ & \multirow{2}{*}{ Structure } & Permeability & K-factor \\
\hline \multicolumn{3}{|c|}{$\%$} & & $\mathrm{Cm} / \mathrm{hr}$ & $M \mathrm{~g} . \mathrm{h} . / M \mathrm{~J} . \mathrm{mm}$ \\
\hline 13.8 & 43.8 & 0.55 & 4 & 1.7 & 0.28 \\
\hline
\end{tabular}

$*$ Vfs $=$ very fine sand

This calculation was performed by the division of rainstorm into segments of uniform intensity .The kinetic energy was calculated for each segment and multiplied by the rainfall during that segment, it gives the total kinetic energy of the segment.The sum of kinetic energies of all segments gives the factor of rainstorm erosivity ( $R=$ $\mathrm{EI}_{30}$ ) of the universal soil loss equation (USLE). The factor of rainstorm erosivity is calculated based on the equation of Wischmeir and Smith (1978) as in the following;

$$
\mathrm{R}=\mathrm{EI}_{30}=\begin{gathered}
(210.3+ \\
-
\end{gathered}
$$

Where:

$\mathrm{R}=\mathrm{EI}_{30}=$ the rainstorm erosivity factor $\left(100 \mathrm{t} . \mathrm{cm} \cdot \mathrm{ha}^{-1} \mathrm{~h}^{-1}\right)$

$\mathrm{I}=$ the rainstorm intensity $\left(\mathrm{cm} . \mathrm{h}_{-}{ }^{1)}\right.$

$\mathrm{I}_{30}=$ Maximal $30-$ minute intensity $\left(\mathrm{cm} . \mathrm{h}^{-1}\right)$

After each rainstorm, runoff samples were taken at the flume outlet and were used to calculate runoff water and mass of soil flow as in the followings.

1- Determination of runoff volume was carried out in the field by measuring the height of the collected water (h) in the tank multiply by the area of the tank base as follow;

$$
\mathrm{RV}=3.14 \mathrm{r}^{2} \mathrm{~h}
$$

Where; $R v=$ Surface runoff volume after each rainstorm $\left(\mathrm{mm}^{3}\right)$

$$
\begin{aligned}
& \mathrm{r}=\text { radius of tank base }(\mathrm{mm}) \\
& \mathrm{h}=\text { height collected water in the tank }(\mathrm{mm})
\end{aligned}
$$

Surface runoff depth resulted from each rainstorm was calculated using the following relationships as mentioned by Oweis and Taimah (1996);

$$
\text { R.D. = - } \frac{\mathrm{Rv}}{\mathrm{Ac}}
$$

Where;

R.D. $=$ Surface runoff depth $(\mathrm{mm})$.

$\mathrm{Rv}=$ Surface runoff volume after each rainstorm (mm3).

$\mathrm{Ac}=$ Catchment area $\left(\mathrm{mm}^{2}\right)$. 
2- Sediment yield and mass of soil loss was determined by evaporation procedure Randomized completely block design was used in this experiment .The data were Regression equations were obtained between rainfall depth and runoff depth.

\section{RESULTS AND DISCUSSION}

Using equations 3 and 4 with daily rainfall data of the studied area, the actual erosive $\left(\mathrm{EI}_{30}\right)$ values of the entire rainstorm during the studied period are obtained and presented in table (3). These erosivity indices $\left(\mathrm{EI}_{30}\right)$ revealed somewhat wide variation in their values. It ranged from 0.011 to 3.392 metric unit with average of 1.725 metric units. This variation in $\mathrm{EI}_{30}$ values means that there is a fluctuation in the amount of annual rainfall depth during the studied period. The calculated erosivity values indicated a high risk at the initial rainy months and showed a low risk at the final rainy month of the water year.

Table (3): Physical analysis of all rainstorm during the studied period

\begin{tabular}{|c|c|c|c|c|c|c|c|}
\hline Date & $\begin{array}{c}\text { Rainfall } \\
\text { Depth } \\
(\mathrm{cm})\end{array}$ & $\begin{array}{c}\text { Duration } \\
(\mathrm{min} .)\end{array}$ & $\begin{array}{c}\text { Intensity } \\
(\mathrm{cm} / \mathrm{h})\end{array}$ & $\begin{array}{c}\text { Energy } \\
\mathrm{E}=210+89 \log \mathrm{I}\end{array}$ & $\begin{array}{c}\text { Total } \\
\text { Energy }\end{array}$ & $\mathrm{I}_{30}$ & $\mathrm{EI}_{30}$ \\
\hline $04 / 11$ & 1.92 & 450 & 0.256 & 157.33 & 302.08 & 0.26 & 0.785 \\
\hline $06 / 11$ & 1.40 & 685 & 0.122 & 128.69 & 180.16 & 0.20 & 0.360 \\
\hline $09 / 11$ & 0.45 & 075 & 0.360 & 170.50 & 076.63 & 0.04 & 0.031 \\
\hline $17 / 11$ & 3.54 & 1130 & 0.187 & 145.19 & 513.98 & 0.66 & 3.392 \\
\hline $22 / 11$ & 1.46 & 1140 & 0.077 & 110.90 & 161.91 & 0.26 & 0.420 \\
\hline $23 / 11$ & 0.30 & 235 & 0.077 & 110.90 & 033.27 & 0.08 & 0.026 \\
\hline $11 / 12$ & 0.60 & 620 & 0.058 & 099.94 & 059.96 & 0.16 & 0.096 \\
\hline $24 / 11$ & 2.31 & 585 & 0.237 & 154.35 & 356.55 & 0.36 & 1.283 \\
\hline $04 / 1$ & 0.41 & 870 & 0.028 & 071.80 & 029.43 & 0.04 & 0.011 \\
\hline $18 / 1$ & 0.71 & 1440 & 0.030 & 074.46 & 052.87 & 0.36 & 0.190 \\
\hline $04 / 2$ & 1.20 & 345 & 0.209 & 149.49 & 179.39 & 0.16 & 0.287 \\
\hline $19 / 2$ & 1.30 & 1440 & 0.054 & 097.18 & 126.33 & 0.18 & 0.227 \\
\hline $04 / 3$ & 1.42 & 870 & 0.097 & 119.82 & 170.15 & 0.18 & 0.306 \\
\hline $03 / 4$ & 0.56 & 1440 & 0.230 & 064.19 & 035.94 & 0.12 & 0.043 \\
\hline $02 / 5$ & 1.56 & 1180 & 0.790 & 111.88 & 174.53 & 0.30 & 0.523 \\
\hline Total & 19.14 & 12505 & 2.8120 & 1766.6 & 2453.2 & 3.2400 & 7.9800 \\
\hline
\end{tabular}

Mass of soil loss and runoff water volume of the dry and moist soil states under each rainstorm during the studied period are presented in table (4). These results showed that the initial moistened of soil flume caused increasing in amount of soil

Loss $(249.53 \mathrm{~kg} / \mathrm{ha}$ and 10.53 liter respectively) at dry state in comparison with the flume of moist soil (488.80 kg/ha. and surface runoff 197.1liter). The average soil loss and runoff volume of the moistened soil treatment was higher than the dry soil treatment through the studied period. This result means that the runoff was delayed for the case of initially moisture content. Runoff water was less on the dry soil state, but greater in the moistened soil in all the rainstorms. This is probably due to formation of 
a depositional seal in that case and concentration of flow as it moved around the soil surface (Mamedove et al .2000).

Table (4): Mass of Soil loss and runoff volume for the two states during the selected rainstorms.

\begin{tabular}{|c|c|c|c|c|}
\hline \multirow{2}{*}{ Date of storm } & \multicolumn{2}{|c|}{ Soil loss kg/ ha. } & \multicolumn{2}{c|}{ Runoff volume (Liter) } \\
\cline { 2 - 5 } & Dry & Moist & Dry & Moist \\
\hline $04 / 11$ & $53.79 \mathrm{a}$ & $78.54 \mathrm{a}$ & $1.38 \mathrm{a}$ & $3.02 \mathrm{a}$ \\
\hline $06 / 11$ & $47.98 \mathrm{a}$ & $56.59 \mathrm{a}$ & $1.68 \mathrm{a}$ & $1.95 \mathrm{a}$ \\
\hline $09 / 11$ & $03.30 \mathrm{a}$ & $04.12 \mathrm{a}$ & $0.21 \mathrm{a}$ & $0.26 \mathrm{a}$ \\
\hline $17 / 11$ & $42.41 \mathrm{~b}$ & $151.47 \mathrm{a}$ & $2.58 \mathrm{a}$ & $6.06 \mathrm{a}$ \\
\hline $22 / 11$ & $12.87 \mathrm{a}$ & $16.01 \mathrm{a}$ & $0.62 \mathrm{a}$ & $0.78 \mathrm{a}$ \\
\hline $23 / 11$ & $02.14 \mathrm{a}$ & $03.96 \mathrm{a}$ & $0.07 \mathrm{a}$ & $0.14 \mathrm{a}$ \\
\hline $11 / 12$ & $05.11 \mathrm{a}$ & $06.93 \mathrm{a}$ & $0.23 \mathrm{a}$ & $0.28 \mathrm{a}$ \\
\hline $24 / 11$ & $17.32 \mathrm{~b}$ & $63.86 \mathrm{a}$ & $1.38 \mathrm{~b}$ & $3.20 \mathrm{a}$ \\
\hline $04 / 1$ & $03.13 \mathrm{a}$ & $04.29 \mathrm{a}$ & $0.20 \mathrm{~b}$ & $0.31 \mathrm{a}$ \\
\hline $18 / 1$ & $06.10 \mathrm{a}$ & $09.41 \mathrm{a}$ & $0.27 \mathrm{a}$ & $0.43 \mathrm{a}$ \\
\hline $04 / 2$ & $04.29 \mathrm{a}$ & $26.53 \mathrm{a}$ & $0.49 \mathrm{a}$ & $0.61 \mathrm{a}$ \\
\hline $19 / 2$ & $06.07 \mathrm{a}$ & $09.40 \mathrm{a}$ & $0.50 \mathrm{a}$ & $0.88 \mathrm{a}$ \\
\hline $04 / 3$ & $21.29 \mathrm{a}$ & $24.92 \mathrm{a}$ & $0.55 \mathrm{a}$ & $0.68 \mathrm{a}$ \\
\hline $03 / 4$ & $16.92 \mathrm{a}$ & $18.50 \mathrm{a}$ & $0.29 \mathrm{a}$ & $0.32 \mathrm{a}$ \\
\hline $02 / 5$ & $06.81 \mathrm{a}$ & $14.27 \mathrm{a}$ & $0.08 \mathrm{a}$ & $0.78 \mathrm{a}$ \\
\hline Total & $249.53 \mathrm{~b}$ & $488.80 \mathrm{a}$ & $10.53 \mathrm{~b}$ & $1971 \mathrm{a}$ \\
\hline
\end{tabular}

*Numbers of similar letter means no significant differences

In the initial state of the rainstorm, when the soil is dry, the rainfall intensity be less than infiltration rate. Gradually , as the rain progresses ,the soil saturated and the infiltration rate reduces to steady rate, therefore the propensity of an area to produce runoff is largely dependent on the total rainfall amount and landscape factors. This can be explained that when water is added to the soil slowly in precipitation , all the water enter the soil surface due to increase the infiltration rate and reduce the potential for runoff. But when the precipitation comes rapidly, the infiltration rate is minimized, resulting maximized runoff. In other word, saturation excess overland flow occurs when the soil becomes saturated, and any additional precipitation causes runoff.

The lag time between peak rainfall and peak runoff is an important index reflecting hydrological properties in a catchment (Aaron and Yassif 2004). To characterize lag times, we studied the effects of rainfall properties, on runoff response in the two soil moisture states statistically. Regression analysis of rainfall depth against runoff depth for dry and initially moistened soil are shown graphically in Fig.1. This relation between rainfall depth and runoff depth is linear, which means that the propensity of the soil to produce runoff is largely dependent on the total rainfall amount and landscape which determining whether or not a particular area in a watershed will generate runoff. Moreover, as rainfall continues the saturated area grows in extent, and causing an increasing in the generating runoff of the area. 

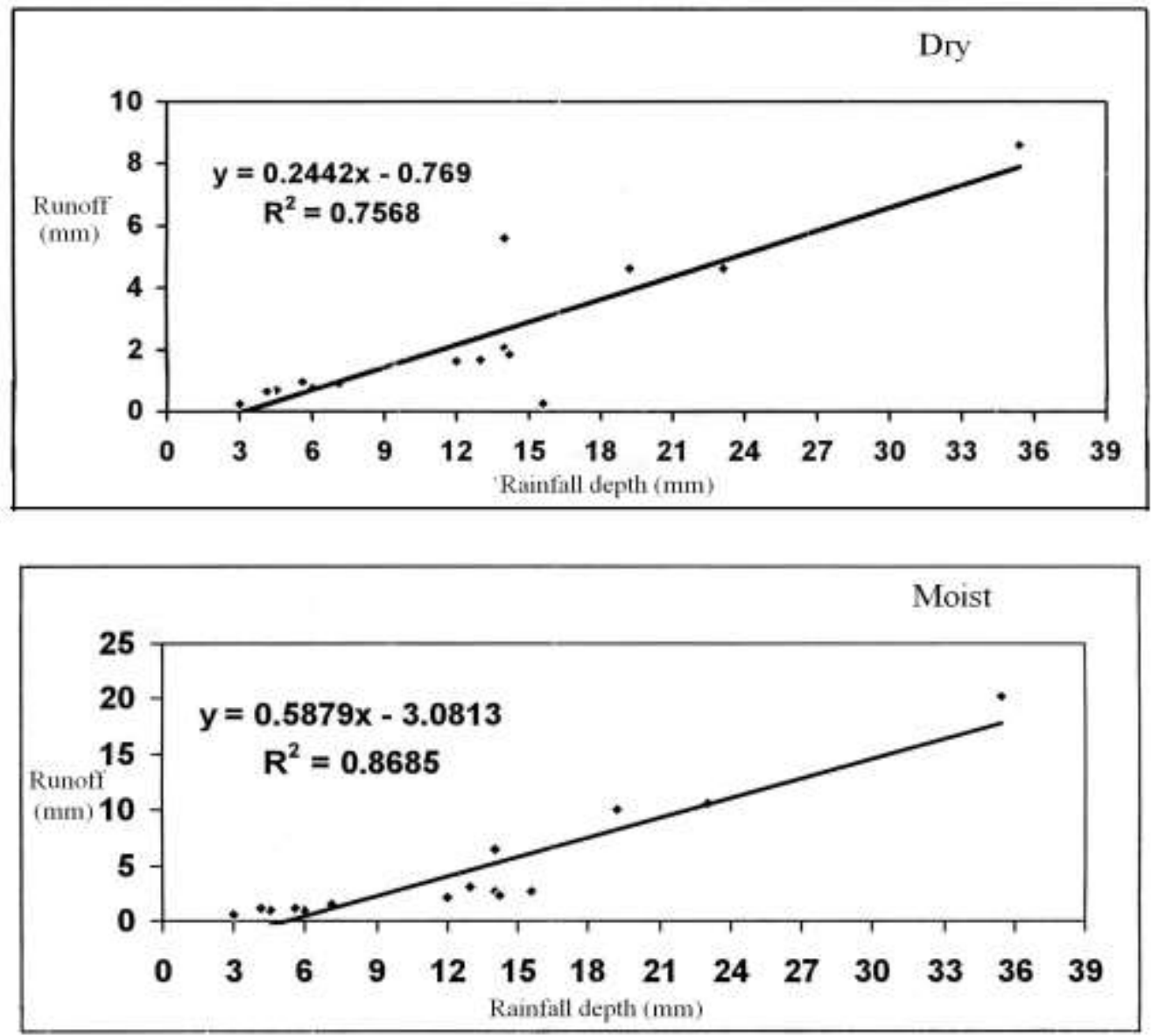

Fig.1. Linear regression relationship for runoff depth * rainfall depth of the two moisture states

Detailed analysis of this statistical relationships (as given in Table 6) showed that the threshold value (coefficient $\mathrm{a} / \mathrm{b}$ for regression equation of rainfall depth against runoff depth) for surface runoff at dry soil state $(3.14 \mathrm{~mm})$ is somewhat higher than that of moist soil state $(5.24 \mathrm{~mm})$. This may be attributed to the fact stated that the dry soil adsorbed all the rainfall energy and needed a high portion of rainfall to generate the flow in comparing with the moistened soil .This result can be shown clearly when comparing the runoff efficiency (b) for the two states which is high $(0.58 \mathrm{~mm})$ in dry state and low in moist soil $(0.24 \mathrm{~mm})$.

Table (5): Regression analysis for runoff $\operatorname{depth}(\mathrm{Y}) *$ rainfall $\operatorname{depth}(\mathrm{X})$ for the two soil moisture states

\begin{tabular}{|c|c|c|c|c|}
\hline $\begin{array}{c}\text { Soil moisture } \\
\text { state }\end{array}$ & $\begin{array}{c}\text { Regression equation } \\
\mathrm{Y}=\mathrm{b} X \pm \mathrm{a}\end{array}$ & $\begin{array}{c}\text { Run-off } \\
\text { threshold } \\
\text { Po=a / b }\end{array}$ & $\begin{array}{c}\text { Run-off efficiency } \\
(\mathrm{b})\end{array}$ & $\mathrm{R}^{2}$ \\
\hline Dry & $\mathrm{Y}=0.2442 \mathrm{X}-0.769$ & 3.14 & 0.24 & 0.76 \\
\hline Moist & $\mathrm{Y}=0.5870 \mathrm{X}-3.0813$ & 5.24 & 0.58 & 0.87 \\
\hline
\end{tabular}


From the results obtained, we concluded that surface runoff generation and soil flow can be caused by at least two different processes, depending on soil properties and antecedent moisture state. Variable source area or saturation-excess runoff occurs when the soil is unable to absorb more rainfall because it is already saturated. Soil erosion accompanies runoff, so humid regions attempt to limit runoff to decrease soil losses from water erosion (Zart et al 2001). Semi-arid and arid regions(as in our location) use similar practices to store and conserve water in the soil because it is not possible to grow a crop on growing season precipitation alone; conversely, dry periods will decrease interflow and extent of saturation. This is illustrated for wet and dry.

$$
\begin{aligned}
& \text { تأثير حالة التربة الرطوبية في حجم السيح السطحي وفقد التربة بالتعرية المائية }
\end{aligned}
$$

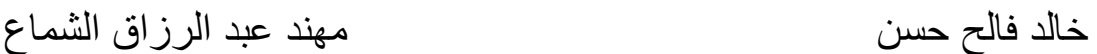

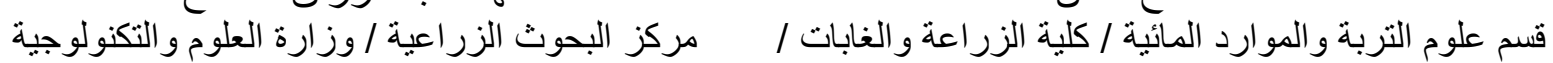

$$
\begin{aligned}
& \text { جامعة الموصل - العراق القدان }
\end{aligned}
$$

\section{الخلاصة}

أجريت در اسة حقلية لتحديد تأثير حالة رطوبة التربة الآنية على حجم السيح السطحي وفقد التربة بالتعريـة

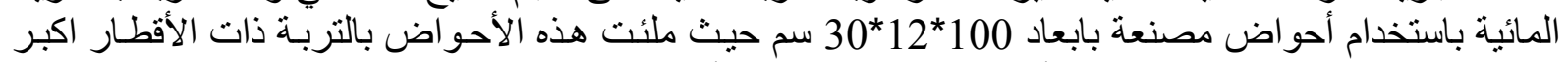

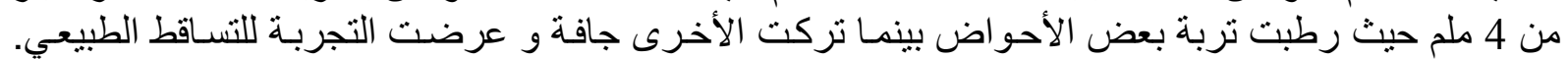

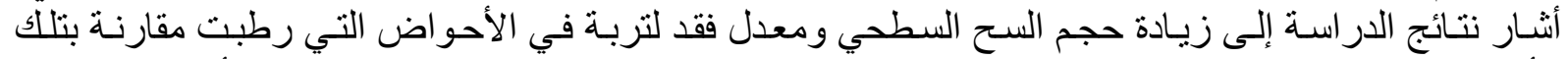

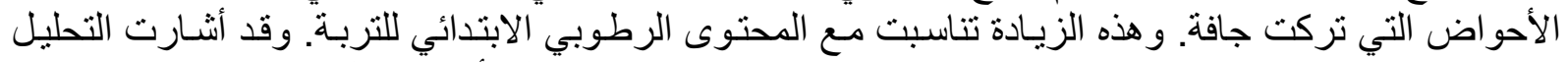

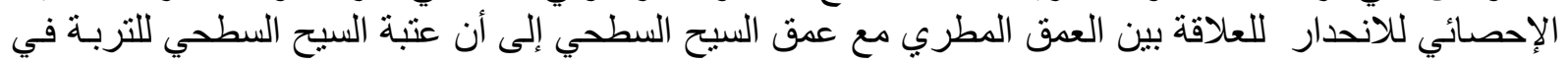

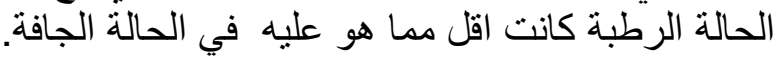

الكلمات الدالة:

تاريخ تسلم البحث: 2012/9/20 ،وقبوله: 2013/3/18.

\section{REFERENCES}

Aaron Y. and N. Raz-Yassif (2004). Hydrological processes in a small arid catchment: scale effects of rainfall and slope length. Geomorphology,61:155169.

Anonymous, (1975). Soil Taxonomy. Agr. Handbook No.436. U.S. Government. Prentic- Hall Office .Washington, DC. U.S.A

Chaudary, J., S. Jalotra and M. Sood (1978). Development of anhypodermic -Needle type rainulator. Journal of Indian Soil Sciencs. Society. 26:87-89.

Dennis, M. and R. Bryan (2000). The relationship of soil loss by interrill erosion to slop gradient. (ARTICLE) CATENA, 38: 211-222.

Klute, A., R. Dinauer, D. Buxton and J. Mortvedt (1986) . Methods Of Soil Analysis Agron. 9 (Part 1), Madison, Wisconsin, USA.

Mamedove, A., I. Shainberg and G.Levy (2000). Wetting rate and sodicity effects of interrill erosion from semi-arid soils (Articles). Soil and Tillage Research. 68 (121-132).

Oweis, T., and A. Taimah (1996). Evaluation of small basin water harvesting system in the arid region of Jordan. Water Resources Management 10:21 -34. 
Mesopotamia J. of Agric. $\quad$ ISSN: 2224 - 9796 (Online)

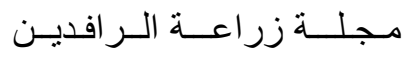

Vol. (45) No. (2) $2017 \quad$ ISSN: 1815 - 316 X (Print)

المجلد (45) العدد (2) 2017

Wischmeir, W. and D.Smith (1978) .Predicting Rainfall Erosion Loss .A Guide To Conservation Planning .Agronomy. Hand book.No.537.USDA.

Zart, A., A. Klik and C. Huang (2001). Soil detachment and transport from interrill and rill areas - (ARTICLE) : Hydrology. 26 (25-26). 